\title{
Chemical constituents of Simarouba versicolor
}

\author{
ANGELA M.C. ARRIAGA ${ }^{1}$, ALDENOR C. DE MESQUITA ${ }^{1}$, YVONE B.M. POULIQUEN ${ }^{1}$, \\ ROBERTO A. DE LIMA ${ }^{2}$, SERGIO H. CAVALCANTE ${ }^{2}$, MARIO G. DE CARVALHO ${ }^{3}$, \\ JOSÉ A. DE SIQUEIRA ${ }^{3}$, LEILA V. ALEGRIO ${ }^{3}$ and RAIMUNDO BRAZ-FILHO ${ }^{4}$ \\ ${ }^{1}$ Departamento de Química Orgânica e Inorgânica, Centro de Ciências, \\ Universidade Federal do Ceará, Cx. Postal 12200, 60021-970 Fortaleza, Ceará, Brasil \\ ${ }^{2}$ Departamento de Química, Universidade Federal de Alagoas, Maceió, Alagoas, Brasil \\ ${ }^{3}$ Departamento de Química - ICE, Universidade Federal Rural do Rio de Janeiro \\ Seropédica, Rio de Janeiro, Brasil \\ ${ }^{4}$ Setor de Química de Produtos Naturais - LCQUI - CCT, Universidade Estadual do Norte Fluminense \\ 28015-620 Campos, Rio de Janeiro, Brazil
}

Manuscript received on March 20, 2001; accepted for publication on December 3, 2001; contributed by RAIMUNDO BRAZ-FILHO*

\begin{abstract}
From the roots, stems and fruits of Simarouba versicolor (Simaroubaceae) were isolated quassinoids $(\mathbf{3}, \mathbf{5 - 7})$, triterpenoids (8-14), a mixture of steroids (15-17), the flavonoid kaempferol (18) and the squalene derivative 11,14-diacetoxy-7,10; 15,18-diepoxy-6,19-dihidroxy-6,7,10,11,14,15,18,19-octahydrosqualene (19). Spectral data were used for structural characterization.
\end{abstract}

Key words: Simarouba versicolor, Simaroubaceae, quassinoids, triterpenoids, steroids, flavonoid, squalene derivative.

\section{INTRODUCTION}

Some species of the small family Simaroubaceae (28 genera containing 25 species of tropical and semitropical shrubs and trees) have furnished wood for construction and others have been used in folk medicine. In the last few years, the therapeutic purposes have increased because of its antimalarial, antiinflammatory, antileukemic, antifeedant, and antiviral activities (Engler and Prantl 1872). In Brazil, the Simaroubaceae family is represented by the genera Quassia and Picrolemma, in the Amazonian Region, Castela and Picrasma, in the south of the country, and Simaba, Simarouba and Picrolemma which are present throughout Brazil (Hall et al. 1983).

Correspondence to: Raimundo Braz-Filho

E-mail: braz@uenf.br

*Member of Academia Brasileira de Ciências
Species of the genus Simarouba have been reported previously as bioproducers of anticancer, antiviral, antimalaric, antiinflammatory (Polonsky 1973), insecticide and amoebacide agents (Polonsky 1985). This latter species has been used in the traditional medicine and is very known in China and Mexico.

Epilupeol (1), four quassinoids (2-5) and $\beta$-sitosterol (15) were previously isolated from the leaves and stems of a specimen of Simarouba versicolor collected in the State of Paraná, Brasil (Ghosh et al. 1977).

The present paper deals with the isolation of the known quassinoids $(\mathbf{3}, \mathbf{5 - 7})$, triterpenoids (814), a mixture of steroids (15-17), the flavonoid kaempferol (18) and a squalene derivative (19) from specimens of Simarouba versicolor collected in Cascavel (stems and fruits) and Pacatuba (roots) in the 
State of Ceará, in the northeastern of Brazil. This region has a very distinct climate, which is different from the place where the specimen was collected for the previous investigation. The structures of the compounds reported in this paper were established on the basis of spectral data, including 2D NMR experiments of $\mathbf{1 9}$.

\section{RESULTS AND DISCUSSION}

The secondary metabolites isolated from Simarouba versicolor, known quassinoids $(\mathbf{3}, \mathbf{5 - 7})$, triterpenoids (8-14), a mixture of steroids (15-17), the flavonoid kaempferol (18) and squalene derivative (19), were identified by their IR, MS, ${ }^{1} \mathrm{H}$ and ${ }^{13} \mathrm{C}$ NMR data, including preparation of some acetyl derivatives (11a, 12a, 13a, 14a and 18a) and comparison with literature data (Merrien and Polonsky 1971, Connolly and McCrindle 1971, Polonsky et al. 1975, Kupchan and Lacadie 1975, Jolad et al. 1981, Suzuki et al. 1985, Hashimoto et al. 1988a,b). The characterization of the squalene derivative $\mathbf{1 9}$ involved additional results obtained by interpretation of homonuclear and heteronuclear 2D shift-correlated spectra facilitated by comparison with data reported in the literature (Itokawa et al. 1991, Morita et al. 1993). The compounds isolated from $S$. versicolor (Fig. 1) reported in this paper were previously obtained from plants classified in the same or other genera of Simaroubaceae or other families.

11-Acetylamarolide (3) was isolated from a specimen of $S$. versicolor collected in Paraná, state located in the South of Brazil (Ghosh et al. 1977).

Glaucarubinone (5) (Alves-de-Lima et al. 1983, Alves-de-Lima et al. 1984, Polonsky et al. 1975) and glaucarubin (6) (Mesquita et al. 1997, Polonsky et al. 1975) were previously obtained from Simarouba glauca (Buckingham 1994a).

2'-Actylglaucarubin (7) (Alves-de-Lima et al. 1984) and tirucalla-7,24-dien-3-one (8) (Alves-deLima et al. 1983, Siqueira et al. 1985) were reported as bioproducts from S. amara (Buckingham 1994b).

20,24 - Epoxy - 25 - hydroxydammaran - 3 - one (ocotillone, 9) (Alves-de-Lima et al. 1982, Siqueira et al. 1985) was reported in the literature as a con- stituent of Dipterus hispidus and Dryanobulanops spp., The CH-24 epimer, cabraleone, has been isolated from Cabralea polytricha (Buckingham 1994c). The relative configurations of carbon atoms C-20 and $\mathrm{CH}-24$ of 9 were deduced by comparison of the chemical shifts of $\mathrm{CH}-24\left(\delta_{\mathrm{C}} 83.56\right)$ and $\mathrm{CH}_{3}$ $21\left(\delta_{\mathrm{C}} 23.75\right)$. The significant differences among values reported in the literature for these carbons (Fig. 2) in ocotillone [9: $\delta_{\mathrm{C}} 84.3(\mathrm{CH}-24)$ and $\delta_{\mathrm{C}}$ $\left.23.3\left(\mathrm{CH}_{3}-21\right)\right]$ and cabraleone [24-epiocotillone: $\delta_{\mathrm{C}} 87.4(\mathrm{CH}-24)$ and $\left.\delta_{\mathrm{C}} 26.3\left(\mathrm{CH}_{3}-21\right)\right]$, two $\mathrm{CH}-$ 24 epimeric compounds (Tanaka and Yahara 1978), were used to characterize the compound isolated from $S$. versicolor as identical to 9 . The lower chemical shifts of $\mathrm{CH}-24\left(\delta_{\mathrm{C}}\right.$ 83.56) and $\mathrm{CH}_{3}-21\left(\delta_{\mathrm{C}}\right.$ 23.75) observed in the ${ }^{13} \mathrm{C}$ NMR spectrum of 9 when compared with the corresponding values of cabraleone (Fig. 2) can be explained by the reciprocal $\gamma$-effects of these carbon atoms in $\mathbf{9}$.

24,25-Epoxy-23-hydroxytirucall-7-en - 3 - one (nilocitin, 10) (Alves-de-Lima et al. 1982, Siqueira et al. 1985) was previously isolated from Simaba cedron, Simaroubaceae (Vieira et al. 1998).

21,24-Epoxy-23,25-dihydroxytirucall-7-en-3 one (bourjutinolone A, 11) (Siqueira et al. 1985) and 21,24-epoxy-3,23,25-trihydroxytirucall-7-ene (3-episapelin A, 12) (Siqueira et al. 1985) were also isolated from Simaba cedron, Simaroubaceae (Vieira et al. 1998), Trichilia hispida, Meliaceae (Jolad et al. 1981), Entandrophragma angolense and E. utile, Meliaceae (Okorie and Taylor 1977). The relative configurations of the stereogenic carbon atoms $\mathrm{CH}-23$ and $\mathrm{CH}-24$ of $\mathbf{1 1}$ were established by comparative analysis of the ${ }^{13} \mathrm{C}$ chemical shifts 37.51 (CH-20), $70.06\left(\mathrm{CH}_{2}-21\right), 36.44\left(\mathrm{CH}_{2}-22\right)$, 64.57 (CH-23), 86.44 (CH-24) and 74.05 (C-25) and values described in the literature (Jolad et al. 1981, Vieira et al. 1998) for bourjutinolone A (11), in combination with the value of the coupling constant ( $J=9.0 \mathrm{~Hz}$ ) observed in the ${ }^{1} \mathrm{H}$ NMR spectra of $\mathbf{1 1}$ and its acetyl derivative 11a, as summarized in Figure 3. Analogous analysis using data obtained by ${ }^{1} \mathrm{H}$ NMR spectra of $\mathbf{1 2}$ and its acetyl derivative 12a (Fig. 4) was employed to identify episapelin A (12). 

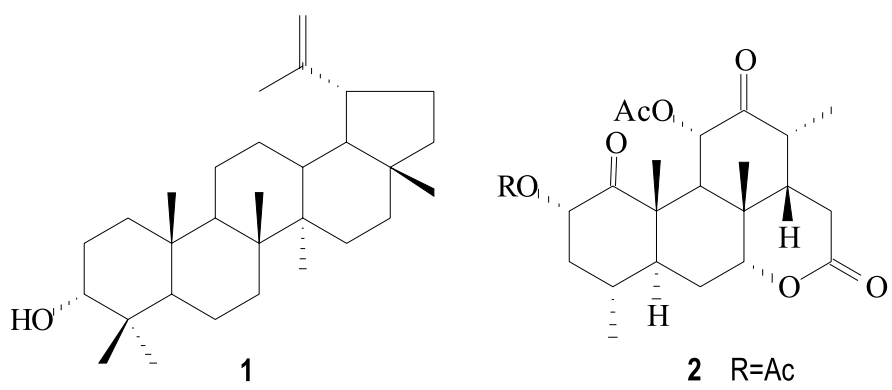

$2 \mathrm{R}=\mathrm{Ac}$

$3 \mathrm{R}=\mathrm{H}$

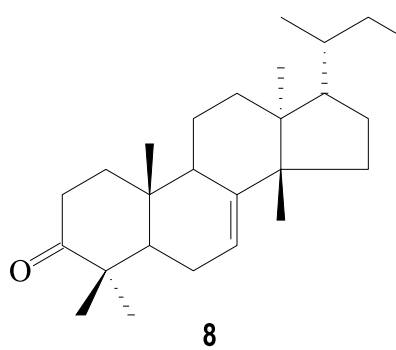

8

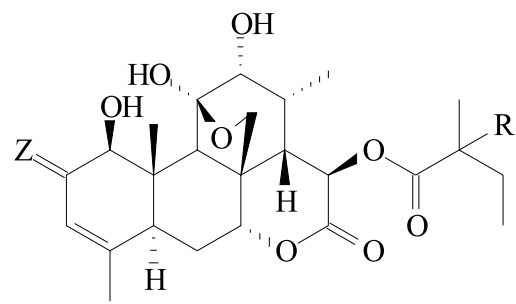

$4 \mathrm{Z}=\mathrm{O} ; \mathrm{R}=\mathrm{H}$

$5 \mathrm{Z}=\mathrm{O} ; \mathrm{R}=\mathrm{OH}$

$6 \mathrm{Z}=\alpha-\mathrm{OH}, \mathrm{H} ; \mathrm{R}=\mathrm{OH}$

$7 \mathrm{Z}=\alpha-\mathrm{OH}, \mathrm{H} ; \mathrm{R}=\mathrm{OAc}$<smiles>[R]O[C@H]1CCCO[C@@H]1C(C)(O)Br</smiles><smiles>CC=C(C)C</smiles><smiles>CC(CC[C@H]1OC1(C)C)[C@H]1CC[C@]2(C)C3=CCC4[C@@H](C)C(=O)CC[C@]4(C)C3CC[C@H]12</smiles>

9

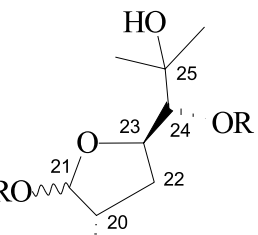

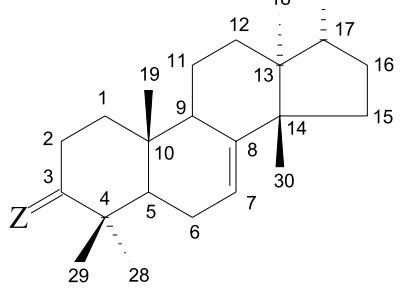

$11 \mathrm{Z}=\mathrm{O} ; \mathrm{R}=\mathrm{H}$

11a $Z=0 ; R=A c$

$12 \mathrm{Z}=\beta-\mathrm{OH}, \mathrm{H} ; \mathrm{R}=\mathrm{H}$

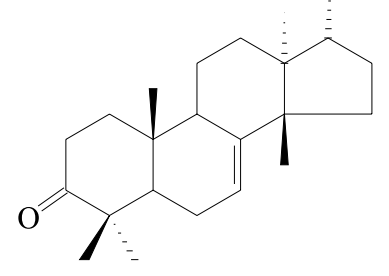

$1321 \beta-\mathrm{OH}, \mathrm{R}=\mathrm{H}$

13a $21 \beta-O A c, R=A c$

$1421 \alpha-\mathrm{OH}, \mathrm{R}=\mathrm{H}$

14a $21 \alpha-O A c, R=A c$

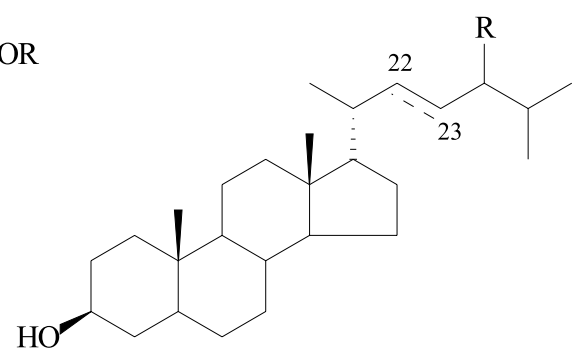

15 22,23-dihydro, R=Et

16 22,23-dihydro, $\mathrm{R}=\mathrm{Me}$

$17 \Delta^{22}, \mathrm{R}=\mathrm{Et}$

OR

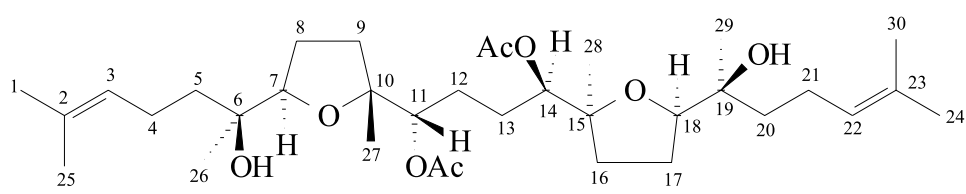

19

$18 \mathrm{R}=\mathrm{H}$

18a $\mathrm{R}=\mathrm{Ac}$

Fig. 1 - Structures for compounds isolated from $S$. versicolor and derivatives. 


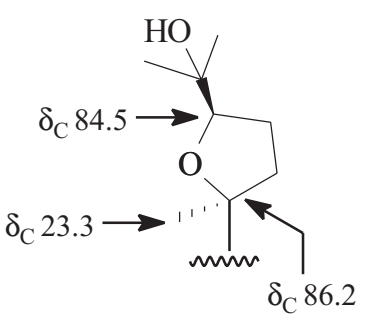

Ocotillone (9)

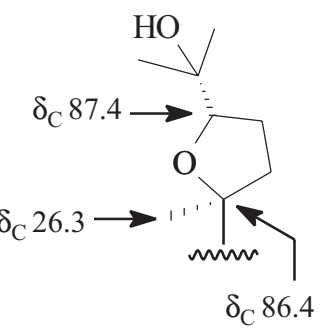

Cabraleone

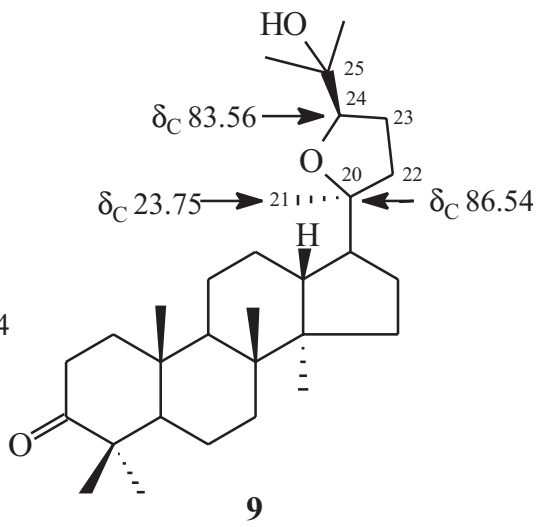

9

Fig. 2 - Comparison of the ${ }^{13} \mathrm{C}$ chemical shifts of the $\mathrm{CH}-24$ methine carbon and $\mathrm{CH}_{3}-21$ methyl of 9 with values described in the literature (Tanaka and Yahara 1978) for ocotilone (9) and cabraleone (24-epiocotilone).

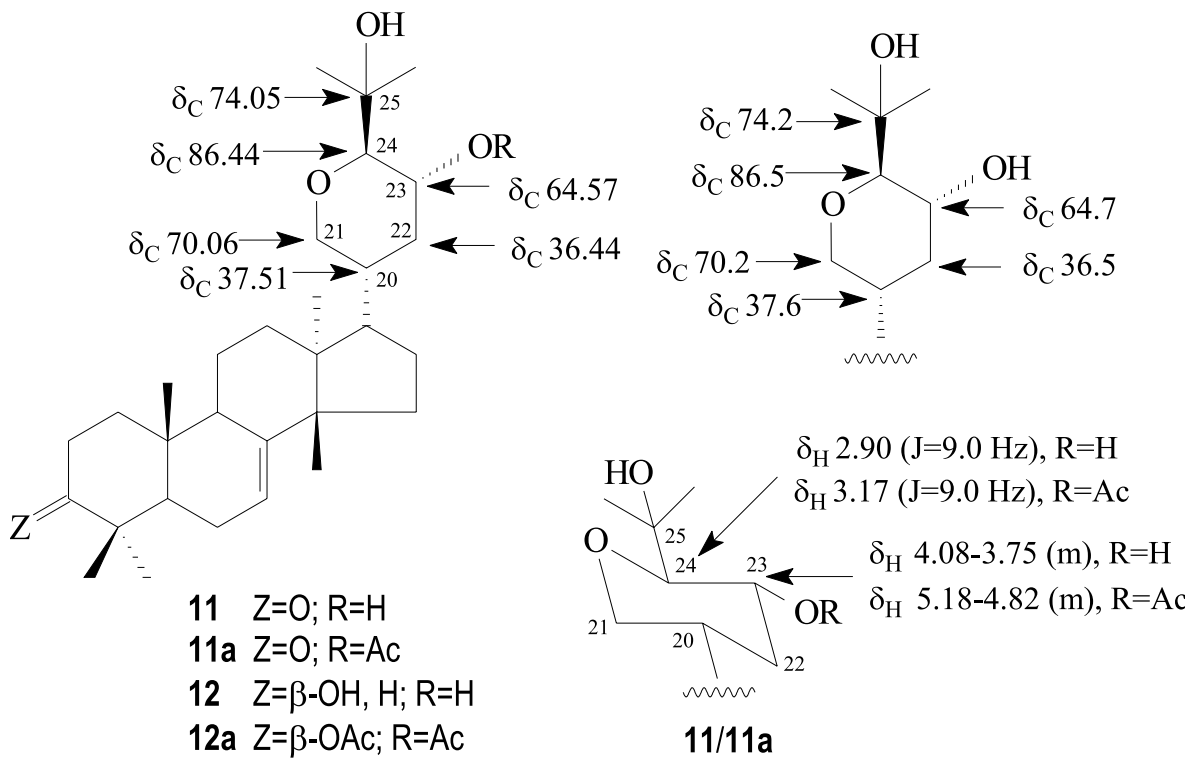

Fig. 3 - Comparison of the chemical shifts of C-20 to C-25 of $\mathbf{1 1}$ with the corresponding values of sapelin $\mathrm{A}(\mathrm{Z}=\alpha-\mathrm{OH}, \mathrm{H} ; \mathrm{R}=\mathrm{H})$ reported in the literature (Jolad et al. 1981. The coupling constant $(J=9.0 \mathrm{~Hz}$ ) observed for signals of $\mathbf{1 1}$ and $\mathbf{1 1 a}$ reveal an axial-axial interaction between $\mathrm{H}-24$ and $\mathrm{H}-23$.

21,23-Epoxy-21 $\beta, 24,25$-trihydroxytirucall- 7en-3-one (13) and 21,23-epoxy-21 $\alpha, 24,25$-trihydroxytirucall-7-en-3-one (14) were isolated as a mixture, clearly recognizable by the signals observed in the ${ }^{13} \mathrm{C}$ NMR spectrum at $\delta_{\mathrm{C}} 102.00 / 96.97$ $(\mathbf{1 3 / 1 4})$ and $83.50 / 78.70(\mathbf{1 3 / 1 4})$ attributed to the methine carbons $\mathrm{CH}-21$ and $\mathrm{CH}-23$, respectively (Fig. 5). The lower chemical shifts of $\mathrm{CH}-21\left(\delta_{\mathrm{C}}\right.$ 96.97) and $\mathrm{CH}-23\left(\delta_{\mathrm{C}} 78.70\right)$ in the epimer 14 (major component) can be explained by a $\gamma$-effect on 


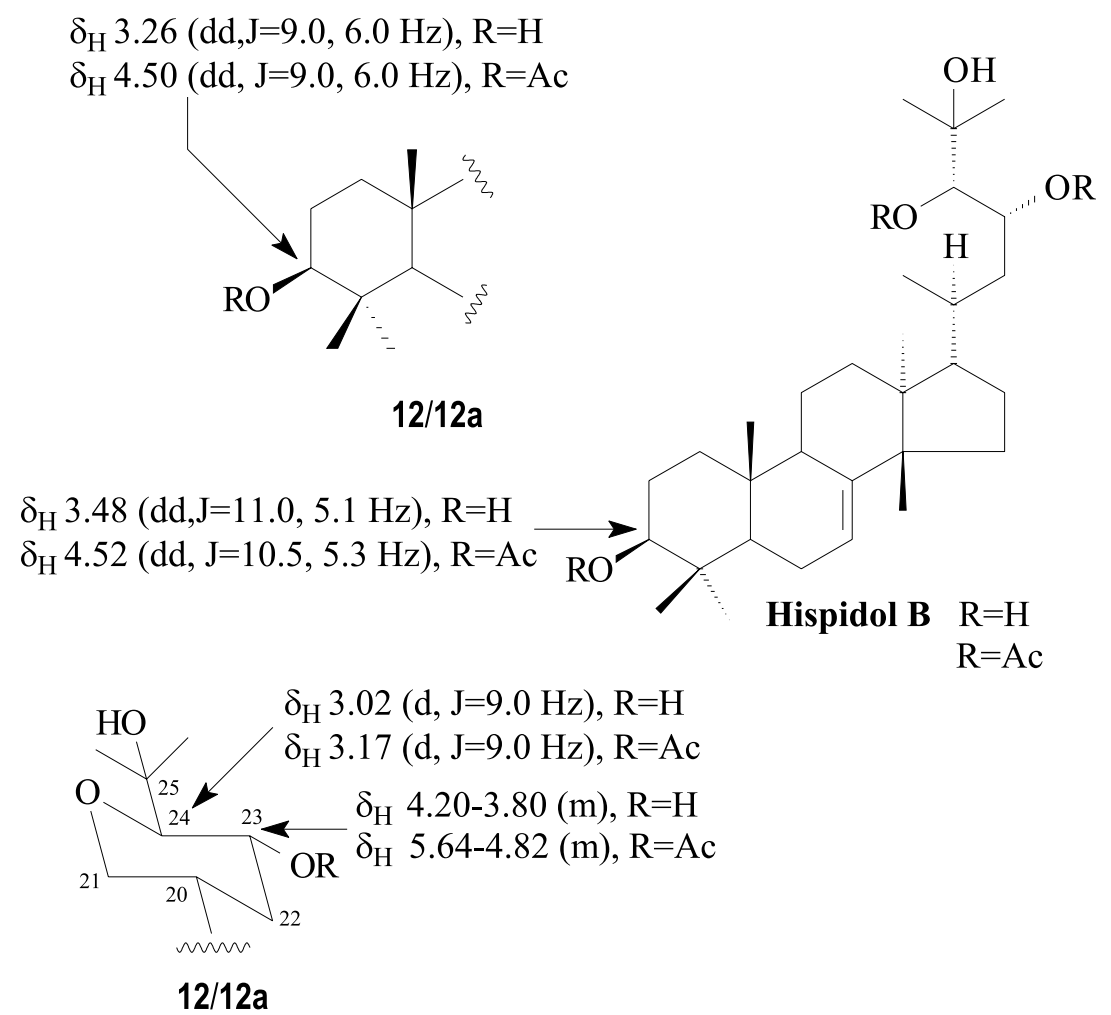

Fig. 4 - Comparison of the ${ }^{1} \mathrm{H}$ chemical shifts of $\mathrm{H}-3$ of $\mathbf{1 2}$ and 12a with the corresponding values for hispidol B and its acetyl derivative reported in the literature (Jolad et al. 1981. The coupling constant $(J=9.0 \mathrm{~Hz})$ observed for signals of $\mathbf{1 2}$ and 12a reveal an axial-axial interaction between $\mathrm{H}-24$ and $\mathrm{H}-23$.

$\mathrm{CH}-23$ by the hydroxyl group located at $\mathrm{CH}-21$ and on $\mathrm{CH}-21$ by the methine carbon $\mathrm{CH}-24$ (Siqueira et al. 1985). Compound $\mathbf{1 4}$ was previously obtained from Samadera madagascariensis, Simaroubaceae (Merrien and Polonsky 1971), when it was mainly characterized through ${ }^{1} \mathrm{H}$ NMR spectral data. On the basis of the relative intensities of the signals corresponding to $\mathrm{H}-21$ in the ${ }^{1} \mathrm{H}$ NMR spectrum the epimer 13 (minor component) was now estimated as $<10 \%$ in the mixture isolated from Simarouba versicolor.

The presence of steroids $\mathbf{1 5 - 1 7}$ in a mixture was mainly deduced by ${ }^{13} \mathrm{C}$ NMR spectral data, which involved comparison with values reported in the literature (Blunt and Stother 1977, Chaurasia and Wichtl 1987). The peaks at $m / z 414$ ([M] ${ }^{+}$. of 15),
$412\left([\mathrm{M}]^{+}\right.$. of 17$)$ and $400\left([\mathrm{M}]^{+}\right.$. of 16) observed in the mass spectrum was also used for the identification of these compounds.

The flavonol kaempferol (18) obtained as its acetyl derivative (18a) (Arriaga et al. 1994) is frequently isolated of plants.

The number of linked hydrogens for each car-

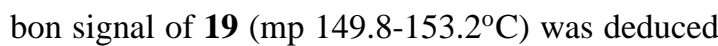
by comparative analysis of HBBD (30 singlet signals corresponding to 34 carbon atoms) and DEPT${ }^{13} \mathrm{C}$ NMR [signals corresponding to 8 quaternary carbons (including two carbonyl of acetyl groups at $\delta_{\mathrm{C}} 170.92$ and 170.78 , which were also suggested by IR spectrum), 5 representing 6 methine carbons (two $\mathrm{sp}^{2}$ and four oxygenated), 10 methylene carbons and 9 representing 10 methyl carbons (two of acetyl 


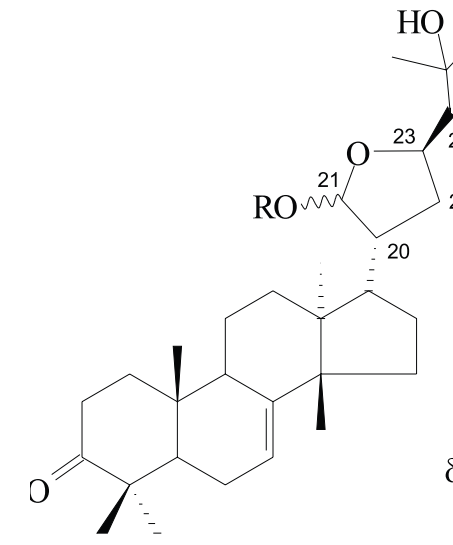

$1321 \beta-\mathrm{OH}, \mathrm{R}=\mathrm{H}$

13a $21 \beta-O A c, R=A c$

$1421 \alpha-\mathrm{OH}, \mathrm{R}=\mathrm{H}$

14a $21 \alpha-O A c, R=A c$

Fig. 5 - Comparison of the ${ }^{13} \mathrm{C}$ chemical shifts of atoms $\mathrm{CH}-21$ and $\mathrm{CH}-23$ of $\mathbf{1 3}$ and $\mathbf{1 4}$ and deduction of the relative configurations.

groups at $\delta_{\mathrm{C}} 21.13$ and 21.07 , in accordance with the singlet signals observed in the ${ }^{1} \mathrm{H}$ NMR at $\delta_{\mathrm{H}}$ 2.03 and 2.04)] spectra (Table I). These data in combination with results obtained by ${ }^{1} \mathrm{H}$ NMR (1D and $\left.2 \mathrm{D}^{1} \mathrm{H}-{ }^{1} \mathrm{H}-\mathrm{COSY}\right)$ and by heteronuclear $2 \mathrm{D}^{1} \mathrm{H}_{-}{ }^{13} \mathrm{C}$ COSY- ${ }^{n} J_{\mathrm{CH}}(\mathrm{n}=1$, direct correlation via one bond HETCOR $-{ }^{13} \mathrm{C}$ detected, conventional method; $\mathrm{n}=2$ and 3, long-range spin-spin interaction - COLOC $-{ }^{13} \mathrm{C}$ detected, conventional method) spectra and comparison with values reported in literature for eurylene (19) (Itokawa et al. 1991, Morita et al. 1993) were used to complete ${ }^{1} \mathrm{H}$ and ${ }^{13} \mathrm{C}$ chemical shift assignments unambiguously. The differences observed in the comparison of the ${ }^{13} \mathrm{C}$ chemical shifts (Table I) may be attributed to mistakes previously reported using $\mathrm{CDCl}_{3}$ as solvent (Itokawa et al. 1991), which was also used in our experiments, or to a solvent effect when the comparative analysis involves data obtained in $\mathrm{CDCl}_{3}$ and pyridine- $d_{5}$ (Morita et al. 1993), as summarized in Table I. The ${ }^{13} \mathrm{C}$ NMR spectral data obtained in pyridine- $d_{5}$ (Morita et al. 1993) were used to eliminate the mistakes observed in the previous attribution when was used $\mathrm{CDCl}_{3}$ (Itokawa et al. 1991). However, the mistakes corre- sponding to $\mathrm{CH}_{3}-25 / \mathrm{CH}_{3}-30\left(\delta_{\mathrm{C}} 17.58\right.$ and not 25.7 or 25.8), shielded as consequence of the $\gamma$-effect attributed to $\mathrm{CH}_{2}-4 / \mathrm{CH}_{2}-21$, and $\mathrm{CH}_{3}-1 / \mathrm{CH}_{3}-24\left(\delta_{\mathrm{C}}\right.$ 25.24 and not 17.6 or 17.7), free of this $\gamma$-effect, were maintained (Table I). On the basis of this $\gamma$ effect, the ambiguous assignments may now be eliminated, as shown in Table I. The results obtained by ${ }^{1} \mathrm{H}-{ }^{1} \mathrm{H}-\mathrm{NOE}$ difference spectra (Table I) were also used to confirm these data and to obtain stereochemical information on some stereogenic carbon atoms of 19. The absolute configuration of eurylene (19), mp $146-148^{\circ} \mathrm{C},[\alpha]_{\mathrm{D}}+4.32^{\circ}$, was established by Xray analysis and Mosher's method (Itokawa et al. 1991, Morita et al. 1993).

\section{EXPERIMENTAL}

\section{General Experimental Procedure}

Melting points (mp) were measured on a Mettler (FP-52) micro-melting point apparatus and are uncorrected; IR spectra were recorded on a PerkinElmer 720 spectrophotometer; ${ }^{1} \mathrm{H}$ and ${ }^{13} \mathrm{C}$ NMR spectra (1D and 2D) were run on Bruker AC-200 $\left({ }^{1} \mathrm{H}: 200 \mathrm{MHz} ;{ }^{13} \mathrm{C}: 50 \mathrm{MHz}\right)$ and Varian XL 100 


\section{TABLE I}

1D and $2 \mathrm{D}{ }^{1} \mathrm{H}$ and ${ }^{13} \mathrm{C}$ NMR spectral data for compound 19 , in $\mathrm{CDCl}_{3}$ and $\mathrm{TMS}$ as internal standard, compared with values (in parenthesis, in $\mathrm{CDCl}_{3}$ and pyridine- $d_{5}$ respectively) described in the literature (Itokawa et al. 1991, Morita et al. 1993) for eurylene (19). Chemical shifts in $\delta\left(\delta_{\mathbf{H}}\right.$ and $\delta_{\mathbf{C}}$, ppm) and coupling constants $(J$, in parenthesis) in Hz.*

\begin{tabular}{|c|c|c|c|c|c|}
\hline & $\delta_{\mathrm{C}}$ & $\delta_{\mathrm{H}}$ & ${ }^{2} J_{\mathrm{CH}}$ & ${ }^{3} J_{\mathrm{CH}}$ & \\
\hline $\mathrm{C}$ & & - & & & \\
\hline $2 / 23$ & $131.54(131.6,130.9)$ & - & $\begin{array}{l}3 \mathrm{H}-1,3 \mathrm{H}-24 / \\
3 \mathrm{H}-25,3 \mathrm{H}-30\end{array}$ & & \\
\hline 6 & $71.92(83.6,72.0)$ & - & $3 \mathrm{H}-26$ & & \\
\hline 10 & $83.55(72.0,84.1)$ & - & H-11, 3H-27 & & \\
\hline 15 & $83.75(72.7,84.1)$ & - & $\mathrm{H}-14,3 \mathrm{H}-28$ & & \\
\hline 19 & $72.64(83.8,72.5)$ & - & $3 \mathrm{H}-29$ & & \\
\hline $\mathrm{AcO}$ & 170.92 (n. d., 170.9) & - & & & \\
\hline $\mathrm{AcO}$ & 170.78 (n. d., 170.7) & - & & & \\
\hline $\mathrm{CH}$ & & & & & ${ }^{1} \mathrm{H}-{ }^{1} \mathrm{H}-\mathrm{NOE}$ \\
\hline $3 / 22$ & $124.43(124.5,125.8 \mathrm{a} / 125.9 \mathrm{a})$ & $5.07(\mathrm{t}, 6.6)$ & & $\begin{array}{l}3 \mathrm{H}-1,3 \mathrm{H}-24 / \\
3 \mathrm{H}-25,3 \mathrm{H}-30\end{array}$ & \\
\hline 7 & $86.52(86.6,87.1)$ & $3.68(\mathrm{dd}, 5.5,9.2)$ & & $3 \mathrm{H}-26$ & \\
\hline 11 & $78.05(78.2,78.4)$ & $4.83(t, 7.0)$ & & $3 \mathrm{H}-27$ & \\
\hline 14 & $77.51(77.6,78.1)$ & $4.85(t, 7.0)$ & & $3 \mathrm{H}-28$ & \\
\hline 18 & $84.30(84.60,85.3)$ & $3.74(\mathrm{dd}, 8.1,6.8)$ & & $3 \mathrm{H}-29$ & \\
\hline \multicolumn{6}{|l|}{$\mathrm{CH}_{2}$} \\
\hline 4,21 & $22.03(22.1,22.7)$ & $2.15-1.85(\mathrm{~m})$ & & & \\
\hline 5 & $37.21(37.3,39.8)$ & $1.45-1.25(\mathrm{~m})$ & & $3 \mathrm{H}-26$ & \\
\hline 8 & $25.64(25.8,26.3)$ & $2.05-1.95(\mathrm{~m}), 1.80-1.70(\mathrm{~m})$ & & & \\
\hline 9 & $34.77(34.9,35.1)$ & $1.66-1.50(\mathrm{~m})$ & & & \\
\hline 12 & $26.94(27.1,27.3 b)$ & $1.54(\mathrm{~m}), 1.25(\mathrm{~m})$ & & & \\
\hline 13 & $26.76(26.9,27.5 b)$ & $1.54(\mathrm{~m}), 1.25(\mathrm{~m})$ & & & \\
\hline 16 & $34.07(34.2,35.0)$ & $1.96-1.82(\mathrm{~m}), 1.58-1.46(\mathrm{~m})$ & & & \\
\hline 17 & $25.47(25.6,26.3)$ & $2.05-1.95(\mathrm{~m}), 1.80-1.70(\mathrm{~m})$ & & & \\
\hline 20 & $37.43(37.6,40.1)$ & $1.45-1.25(\mathrm{~m})$ & & $3 \mathrm{H}-29$ & \\
\hline \multicolumn{6}{|l|}{$\mathrm{CH}_{3}$} \\
\hline $1 / 24$ & $25.64(17.6,17.6 \mathrm{c} / 17.7 \mathrm{c})$ & 1.65 (br s) & & $3 \mathrm{H}-25 / 3 \mathrm{H} 30$ & $\mathrm{H}-3 / \mathrm{H}-22(3 \%)$ \\
\hline $25 / 30$ & $17.58(25.7,25.8)$ & $1.58(\mathrm{br} \mathrm{s})$ & & $3 \mathrm{H}-1 / 3 \mathrm{H}-24$ & \\
\hline 26 & $24.10(24.2,23.2)$ & $1.14(\mathrm{~s})$ & & & H-7 (2\%) \\
\hline 27 & $22.71(22.8,22.9)$ & $1.12(\mathrm{~s})$ & & & $\mathrm{H}-11(<1 \%)$ \\
\hline 28 & $22.50(22.5,22.1)$ & $1.14(\mathrm{~s})$ & & & $\mathrm{H}-14(<1 \%)$ \\
\hline 29 & $23.97(24.0,23.1)$ & $1.15(\mathrm{~s})$ & & & $\mathrm{H}-18(2 \%)$ \\
\hline $\mathrm{AcO}$ & 21.13 (n. d., 21.1) & $2.03(\mathrm{~s})$ & & & \\
\hline Aco & 21.07 (n. d., 21.0) & $2.04(\mathrm{~s})$ & & & \\
\hline
\end{tabular}

*Chemical shifts $(\delta)$ and coupling constants ( $J$ in Hz, in parenthesis) obtained from the one-dimensional ${ }^{1} \mathrm{HNMR}$ spectrum. Multiplicity of signals of carbon atoms deduced by comparative analysis of HBBD and DEPT- ${ }^{13} \mathrm{C}$ NMR spectra. $2 \mathrm{D}{ }^{1} \mathrm{H}-{ }^{1} \mathrm{H}-\mathrm{COSY}$ NMR spectrum was also used for these assignments. Values with the same letter can be interchanged (Morita et al. 1993). n.d.= non described. 
$\left({ }^{1} \mathrm{H}: 100 \mathrm{MHz} ;{ }^{13} \mathrm{C}: 25 \mathrm{MHz}\right)$ spectrometers, using $\mathrm{CDCl}_{3}$ and pyridin- $d_{5}$ as solvents; EIMS were recorded on Micro Mass instrument at $70 \mathrm{eV}$.

\section{Plant Material}

The roots, stems and fruits of S. versicolor were collected in Pacatuba in 1981 and Cascavel in 1997, respectively, Ceará State, Brazil and were identified by Professors Afranio Fernandes and E. Nunes, Departamento de Biologia, Universidade Federal do Ceará (UFC), Fortaleza, Ceará, Brasil. A voucher specimen (number 20.795) has been deposited at Prisco Bezerra Herbarium, Departamento de Biologia, UFC.

\section{EXTRACTION AND ISOLATION}

Dry and powdered roots (480g) were extracted, at room temperature, with hexane and following with acetone. The residue obtained from the acetone extract, after evaporation of the solvent under vacuum, was chromatographed on a silica gel column to give the compounds 5 to 13,19 and a mixture of the steroids 15, 16 and 17 (Alves-de-Lima et al. 1982, Alves-de-Lima et al. 1983, Alves-de-Lima et al. 1984, Siqueira et al. 1985).

The air-dried and powdered stems of S. versicolor $(4.0 \mathrm{~kg})$ were extracted with hot $\mathrm{EtOH}$ in a Soxhlet system. The organic layer was concentrated to give residue SVE (96.0g) which was filtered through 200g of silica gel 60 (Merck, 230-400 mesh) by elution with hexane, chloroform, ethyl acetate and methanol, furnishing after evaporation of the solvent SVH (13.4g), SVC (14.0g), SVAE (12.7g) and SVM (49.5g). SVH (7.5g) which were chromatographed over silica gel 60 (Merck, 230400 mesh) column and eluted with hexane, chloroform and ethyl acetate. The fractions eluted with $\mathrm{CH}_{3} \mathrm{Cl} /$ EtOAc mixture of increasing polarity, afforded $19\left(50.0 \mathrm{mg}, \mathrm{mp} .149 .8-153.2^{\circ} \mathrm{C}\right) . \mathrm{SVC}$ (5.6g) which was chromatographed over silica gel 60 (Merck, 230-400 mesh) column and eluted with hexane, chloroform and ethyl acetate mixtures of increasing polarity. The $\mathrm{CH}_{3} \mathrm{Cl} / \mathrm{EtOAc}(20 \%)$ fraction furnished $\mathbf{3}\left(50.0 \mathrm{mg}, \mathrm{mp} .158 .1-159.3^{\circ} \mathrm{C}\right)$ after recrystallization from methanol. SVAE $(7.0 \mathrm{~g})$ was chromatographed over silica gel 60 (Merck, 230400 mesh) using pure hexane, mixture of hexane and chloroform, chloroform, ethyl acetate and methanol as solvents. The fractions eluted with EtOAc afforded colorless crystals $(30.0 \mathrm{mg}$ ) of $\mathbf{6}$ (mp. 240.6241. $\left.6^{\circ} \mathrm{C}\right)$.

The fruits $(500.0 \mathrm{~g})$ were crushed and extracted with hot ethanol in a Soxhlet system. The organic layer was concentrated to give SVFE (11.8g). This residue was chromatographed on $100.0 \mathrm{~g}$ silica gel 60 (Merck, 230-400 mesh) and eluted with hexane, chloroform, ethyl acetate and methanol to furnish SVFAE (9.0g) and SVFM (2.7g). SVFAE (3.2g) was acetylated with $\mathrm{Ac}_{2} \mathrm{O}(32 \mathrm{~mL})$ in the presence of pyridine $(16 \mathrm{~mL})$, at room temperature and stirred overnight. After the usual procedures, the product was extracted with $\mathrm{Me}_{2} \mathrm{O}$ and chromatographed on a silica gel 60 (Merck, 230-400 mesh) column and eluted with hexane, chloroform, ethyl acetate and methanol. After recrystallization from $\mathrm{MeOH}$, the $\mathrm{CH}_{3} \mathrm{Cl} /$ EtOAc (10\%) fraction furnished the acetyl derivative $17 \mathbf{a}\left(50.0 \mathrm{mg}\right.$, mp. $182.6-185.0^{\circ} \mathrm{C}$ ).

\section{ACKNOWLEDGMENTS}

The authors are grateful to FUNCAP, FAPERJ and CNPq for grants and research fellowships; to Professor Afranio Fernandes and E. Nunes, Departamento de Biologia, Universidade Federal do Ceará (UFC), Fortaleza, Ceará, Brasil for the botanical identification and to Prof. E.R. Silveira for the NMR spectra recorded by the technician Daniel Esdras Uchoa (M.Sc.).

\section{RESUMO}

Das raízes, galhos e frutos de Simarouba versicolor foram isolados quassinóides $(\mathbf{3}, \mathbf{5 - 7})$, triterpenóides (8-14), uma mistura de esteróides (15-17), o flavonóide canferol (18) e o derivado esqualênico 11,14-diacetoxi-7,10;15,18-diepóxi-6,19-diidroxi-6, 7, 10.11, 14, 15, 18, 19-octaidroesqualeno (19). Dados espectrais foram usados para caracterização estrutural.

Palavras-chave: Simarouba versicolor, Simaroubaceae, 
quassinóides, triterpenóides, esteróides, flavonóide, derivado esqualênico.

\section{REFERENCES}

Alves-de-Lima R, Cavalcante SH, Braz-Filho R AND Alegrio LV. 1982. Constituintes químicos de Simarouba versicolor. Ciência e Cultura 34 (supl.): 519-519.

Alves-de-Lima R, Cavalcante SH, Alegrio LV, Geraldo-de-Carvalho M and Braz-Filho R. 1983. Constituintes químicos de Simarouba versicolor. Ciência e Cultura 35 (supl.): 447447.

Alves-de-Lima R, Cavalcante SH, Braz-Filho R; Geraldo-de-Carvalho M, Siqueira PS and AleGRIO LV. 1984. Quassinóides de Simarouba versilcolor. Ciência e Cultura 36 (supl.): 541-541.

Arriaga AMC, Mesquita AG and Braz-Filho R. 1994. Estudo químico dos frutos de Simarouba versicolor. Livros de Resumos-SBQ: PN-85.

Blunt JW ANd Stother JB. 1977.13C NMR Spectra of Steroids - A Survey and Commentary. Org Magn Reson 9: 439-464.

Buckingham J. ED. 1994a. Dictionary of Natural Products, Chapman \& Hall, London, vol. 3, p. 2555. 1994b, Vol. 5, p. 5638. 1994c. Vol. 2, p. 2063.

Chaurasia N and Wichtl M. 1987. Sterols and Steryl Glycosides from Urtica dioica. J Nat Prod 50: 881885.

Connolly JD And McCRindle R. 1971. Tetranortriterpenoids and Related Substances. Part III. The Constitution of Grandifoliolenone, an apo-Tirucallol Derivative from Khaya grandifoliola (Meliaceae). J Chem Soc (C): 1715-1718.

Engler A And Prantl K. 1872. Simaroubaceae. Mart Fl Bras. Munchen 12: 198-202.

Ghosh PC, Larrahondo JE, Quesne PW and RaFFAUF RF. 1977. Antitumor Plants. IV. Constituents of Simarouba versicolor. J Nat Prod 40: 364-369.

Hall IH, LeE KH, ImaKura Y, OKano M and Johnson A. 1983. Antiinflammatory Agents. III. Structureactivity relationships of brusatol and related quassinoids. J Pharm Sci 72: 1282-1284.

Hashimoto M, Harigaya H, Yanagiya M and ShiraHAMA H. 1988a. A Short Step Synthesis of Teurilene. Stereocontrolled Sequential Double Cyclization of the $\mathrm{C}_{30}$-tetraenetetraol to the Tandem Tetrahydrofuran System. Tetrahedron Letters 29: 5947-5948.

Hashimoto M, YanagiYa M and Shirahama H. 1988b. Total Synthesis of meso-Triterpene Ether, Teurilene. Chem Letters: 645-646.

Itokawa H, Kishi E, Morita H, Takeya K and Itaka Y. 1991. Eurylene, a New Squalene-type Triterpene from Eurycoma longifolia. Tetrahedron Letters 32: 1803-1804.

Jolad SD, Hoffmann JJ, Schram KH, Cole R, TemPESTA MS AND BATES RB. 1981. Constituents of Trichilia hispida (Meliaceae). 4. Hispidols A and B, Two New Tirucallane Triterpenoids. J Org Chem 46: 4085-4088.

Kupchan SM and LaCadie JÁ. 1975. Dehydroailanthinone, a New Antileukemic Quassinoid from Pierreodendron kerstingii. J Org Chem 40: 654-657.

Merrien A And Polonsky J. 1971. The Natural Occurrence of Melianodiol and Its Diacetate in Samadera madagascariensis (Simaroubaceae): Model Experiments on Melianodiol Direct towards Simarolide. J C S Chem Commun: 261-262.

Mesquita AG, Arriaga AMC, Oliveira FA and BraZFilho R. 1997. Quassinóide de Simarouba versicolor. Livros de Resumos-SBQ: PN-028.

Morita H, Kishi E, TAKeya K, ITOKaWa H AND ItTAKa Y. 1993. Squalene Derivatives from Eurycoma longifolia. Phytochemistry 34: 765-771.

OKORIE DA AND TAYlor DAH. 1977. Triterpenes from seeds of Entandrophragma species. Phytochemistry 16: 2029-2030.

PolOnsky J. 1973. Quassinoid Bitter Principles. Fortschr Chem Org Nat 30: 101-150.

POLONSKY J. 1985. Quassinoid Bitter Principles II. Fortschr Chem Org Nat 47: 221-264.

Polonsky J, Baskévitch Z, Gottlieb He, Hagaman EW and Wenkert E. 1975. Carbon-13 Nuclear Magnetic Resonance Spectral Analysis of Quassinoid Bitter Principles. J Org Chem 40: 2499-2504.

Siqueira JAP, Braz-Filho R, Alves-De-Lima R and Cavalcante SH. 1985. 3-Hidroxitriterpenóide isolado de Simarouba versicolor. Ciência e Cultura 37 (supl.): 519-519.

Suzuki T, Suzuki M, Furusaki A, Matsumoto T, Kato A, Imanaka Y and Kurosawa E. 1985. 
Teurilene and Thyrsiferyl 23-Acetate, meso and remarkably Cytotoxic Compounds from the Marine Red Alga Laurencia obtusa (Hudson) Lamouroux. Tetrahedron Letters 26: 1329-1332.

Tanaka O and Yahara S. 1978. Dammarane saponins of leaves of Panax pseudo-ginseng subsp. himailacus. Phytochemistry 17: 1353-1358.
Vieira IJC, Rodrigues-Filho E, Vieira PC, Silva MFGF AND FERNANDES JP. 1998. Quassinoids and protolimonoids from Simaba cedron. Fitoterapia 49: 88-90. 